\title{
A szájüreg baktériumflórájának összefüggése az anastomosiselégtelenség következményeivel nyelőcső- és cardiatumoros betegeknél
}

\author{
Balázs Ákos dr. ${ }^{1}$ - Winkler Beáta ${ }^{2}$ - Kristóf Katalin dr. ${ }^{3}$ \\ Harsányi László dr. ${ }^{1}$ - Bokor Lívia dr. ${ }^{1}$ \\ Semmelweis Egyetem, 'Általános Orvostudományi Kar, I. Sebészeti Klinika, \\ ${ }^{2}$ Általános Orvostudományi Kar, Tudományos Diákkör, \\ ${ }^{3}$ Laboratóriumi Medicina Intézet, Klinikai Mikrobiológiai, Diagnosztikai Laboratórium, Budapest
}

\begin{abstract}
Bevezetés: A tumor miatt végzett műtétek során készült nyelőcső-anastomosisok elégtelensége kapcsán az insufficientián át kilépő tartalom bakteriális összetételének a szövődmény kimenetelében jelentős befolyásoló szerepét tételezhetjük fel. Célkitüzés: A vizsgálat célja az anastomosiselégtelenség következményeinek összevetése a betegek szájüregi bakteriális flórájával. Módszer: A prospektív vizsgálat során 131, mútétre került betegnél közvetlenül a mútét előtti órákban mintavételt végeztünk. A betegek szájüregi flórájának összetételét elemeztük. Az anastomosiselégtelenség következményei és a baktériumflóra összetétele közötti korrelációt vizsgáltuk. Eredmények: Patogén baktérium jelenléte a szájüregi flórában 50 esetben $(38,2 \%)$ volt kimutatható. A szövődmény súlyossága és a patogén baktériumok előfordulási gyakorisága között a korrelációanalízis közepes erősségű kapcsolatot mutatott ki $\left(\mathrm{r}_{\mathrm{s}}=0,553\right)$, az eredmény szignifikáns $(\mathrm{p} \leq 0,05)$. Következtetések: A patogén ágenseket tartalmazó flóra a varratelégtelenség eseteiben nagyobb kockázatot és súlyosabb kimenetelt eredményezhet, a meghatározó tényezők egyikeként értékelhető. A szájüregi bakteriális flóra a mütéti előkészítés során a korábbiaknál nagyobb figyelmet és a mütéti előkészítés gyakorlatának megváltoztatását igényli. Orv. Hetil., 2017, 158(1), 25-30.
\end{abstract}

Kulcsszavak: szájüregi baktériumflóra, nyelőcsőtumor, anastomosiselégtelenség, mútéti előkészítés

\section{Relationship of consequences of anastomotic insufficiency and bacterial flora of oral cavity in patients with esophageal and cardia cancer}

Introduction: In the course of anastomotic insufficiency following resection of esophageal cancers the bacterial compound of the esophageal substance has a remarkable, presumable role in the outcome of complications. Aim: The purpose of this study is to compare the consequences of the anastomotic leak with the bacterial flora of patients' oral cavity. Method: In this prospective study a total of 131 patients were investigated directly before the surgical intervention taking a bacterial sample. Bacterial flora of patients' oral cavity was analysed; and the correlation between the consequences of the anastomotic leak and the content of the bacterial flora was examined. Results: Pathogenic bacteria in the oral microflora in 50 cases $(38.2 \%)$ was found. Statistically significant, moderate correlation was found between the severity of the complication and the incidence of pathogenic bacteria $\left(r_{s}=0.553 ; p \leq 0.05\right)$. Conclusions: Pathogenic agent in the microbial flora might induce higher risk and more severe outcome in case of anastomotic leakage and it might be evaluated as a determinative factor. Consideration of the bacterial flora of the oral cavity requires more attention in the preoperative preparation than before and it demands the change of the current practice.

Keywords: oral bacterial flora, esophageal tumor, anastomotic leakage, preoperative preparation

Balázs, Á., Winkler, B., Kristóf, K., Harsányi, L., Bokor, L. [Relationship of consequences of anastomotic insufficiency and bacterial flora of oral cavity in patients with esophageal and cardia cancer]. Orv. Hetil., 2017, 158(1), 25-30.

(Beérkezett: 2016. október 4.; elfogadva: 2016. november 5.) 
A nyelőcső- és cardiatumor miatt végzett reszekciós mütétek egyik legsúlyosabb szövődménye az anastomosiselégtelenség. Irodalmi adatok szerint $0,5-30 \%$-os gyakorisággal fordul elő, de az átlagostól jelentősen eltérő közlésekkel is találkozhatunk [1-6]. A szövődmény kapcsán a nyelőcső ürteréből kilépő és a szövet közti térbe kerülő tartalom meghatározó eleme a felső gastrointestinalis traktus, azon belül is a szájüreg-garat bakteriális flórája. A szövődmény kimenetelét számos tényező határozza meg, ezek között a bakteriális összetételnek jelentősége lehet. Vizsgálatunk során a szájüregi flóra normális összetételtől (1. táblázat) való eltérését vizsgáltuk, valamint kerestük a szövődmények súlyosságának összefüggését a bakteriális flóra sajátosságaival.

1. táblázat |A szájüreg normális bakteriális flórájának gyakoribb összetevői

\begin{tabular}{l}
\hline Staphylococcus epidermis \\
Streptococcus (mitis, salivarius, mutans, sanguis) \\
Proteus (mirabilis, hauseri) \\
Neisseria subflava \\
Prevotella (intermedia, loescheii) \\
Lactobacillus acidophilus \\
Corynebacterium (pseudodiphteriticum, xerosis) \\
Haemophilus parainfluenzae \\
Gemella (sanguinis, haemolysans) \\
Mycobacterium (fortuitum, triviale) \\
Veillonella atypica \\
Porphyromonas gingivalis \\
Campylobacter rectus \\
Capnocytophaga (gingivalis, ochracea) \\
Enterococcus aerogenes \\
Fusobacterium nucleatum \\
Selenomonas sputigena \\
Treponema (medium, denticola) \\
Bacteroides (fragilis, melaninogenicus) \\
Haemophilus influenzae \\
Actinomyces (naesludii, viscosus, israeli) \\
Mycoplasma (fermentans, salivarium, orale) \\
\end{tabular}

Források:

Pál, T.: Az orvosi mikrobiológiai tankönyve. Medicina Könyvkiadó, Budapest, 2013.

Samaranayake, L. P.: Essential microbiology for dentistry. Churchill Livingstone, Edinburg, 2002.

Mandell, G. L., Bennett, J. E., Dolin, R.: Priciples and practice of infections disease. Churchill Livingstone, Philadelphia, 2010.

Aas, J. A., Paster, B. J., Stokes, L. N., et al.: Defining the normal bacterial flora of the oral cavity. J. Clin. Microbiol., 2005, 43(11), 57215732 .

Majumdar, S., Singh, A. B.: Normal microbial flora of oral cavity. J. Adv. Med. Dent. Sci. Res., 2014, 2(4), 62-66.
2. táblázat A vizsgált 131 betegnél történt mútéti beavatkozás, anastomosisszövődmény és a patogén baktériumflóra jelenléte a szájüregi mintában

\begin{tabular}{|c|c|c|c|c|c|}
\hline Mütéti típus & Pótlási út & $\begin{array}{l}\text { Anasto- } \\
\text { mosis }\end{array}$ & Eset & Insuff. & $\begin{array}{l}\text { Patogén } \\
\text { flóra }\end{array}$ \\
\hline $\begin{array}{l}\text { Transhiatalis } \\
\text { oesophagusexstirpáció }\end{array}$ & $\begin{array}{l}\text { Retro- } \\
\text { sternalis }\end{array}$ & Nyaki & 20 & 14 & $\begin{array}{l}11 \\
(55 \%)\end{array}$ \\
\hline $\begin{array}{l}\text { Thoracotomia } \\
\text { oesophagusexstirpáció }\end{array}$ & $\begin{array}{l}\text { Retro- } \\
\text { sternalis }\end{array}$ & Nyaki & 19 & 11 & $\begin{array}{l}11 \\
(57,9 \%)\end{array}$ \\
\hline $\begin{array}{l}\text { Thoracotomia } \\
\text { oesophagusexstirpáció }\end{array}$ & $\begin{array}{l}\text { Orto- } \\
\text { thopicus }\end{array}$ & Nyaki & 7 & 0 & $\begin{array}{l}2 \\
(28,6 \%)\end{array}$ \\
\hline Cardiareszekció & $\begin{array}{l}\text { Abdo- } \\
\text { minalis }\end{array}$ & Distalis & 20 & 6 & $\begin{array}{c}4 \\
(20 \%)\end{array}$ \\
\hline Gastrectomia & $\begin{array}{l}\text { Abdo- } \\
\text { minalis }\end{array}$ & Distalis & 27 & 7 & $\begin{array}{l}9 \\
(33,3 \%)\end{array}$ \\
\hline $\begin{array}{l}\text { Exploráció } \\
\text { thoracotomia/ } \\
\text { laparotomia }\end{array}$ & & & 30 & & $\begin{array}{l}11 \\
(36,7 \%)\end{array}$ \\
\hline $\begin{array}{l}\text { Szupportív mútét } \\
\text { Gastrostomia/ } \\
\text { jejunostomia }\end{array}$ & & & 8 & & $\begin{array}{c}2 \\
(25 \%)\end{array}$ \\
\hline Összesen & & & 131 & 38 & $\begin{array}{l}50 \\
(38,2 \%)\end{array}$ \\
\hline
\end{tabular}

\section{Módszer}

A prospektív vizsgálat során 2012. szeptember 1. és 2015. szeptember 1. között, a Semmelweis Egyetem I. Sebészeti Klinikáján malignus nyelőcső- és cardiatumor diagnózisával mútétre került 131 betegnél szájüregi baktérium-mintavételt végeztünk. A betegek vizsgálatba való bevonása véletlenszerú volt.

A vizsgált betegek közül anastomosis képzésére 93 esetben került sor, ez 46 esetben nyaki és 47 esetben a distalis szakaszon készült. Distalis anastomosist ebben a betegcsoportban a cardiatumor miatt végzett abdominalis nyelő́csőszakasz-, cardia- és proximális gyomorrészlet eltávolítása után (20 eset), valamint az abdominalis nyelőcsőszakasz gyomor egészével együtt történő eltávolítását (27 eset) végeztük. 30 esetben inoperábilis viszonyok miatt csak exploráció, nyolc esetben szupportív (nutritív gastrostomia/jejunostomia) mútét történt (2. táblázat).

A mintavételt közvetlenül a mútéti beavatkozást megelőző órákban, steril leoltópálcával (Eurotubo collection swab, Manufacturer IASA, 08191 Rubi, Spanyolország) végeztük. A betegek orális higiénés szokásait és a mútéti elókészítés szokásos rendjét a vizsgálatba bevont betegeknél a vizsgálat elótt nem befolyásoltuk. A betegek a rutinszerú Ceftriaxon $2 \mathrm{~g}$, Metronidazol $500 \mathrm{mg}$ (iv.) antibiotikum-profilaxist a mintavétel után kapták meg. A minták bakteriológiai feldolgozása az esetek legnagyobb részében, rutinszerú rendszerben, a Semmelweis Egyetem, Laboratóriumi Medicina Intézet Mikrobiológiai Laboratóriumában, néhány esetben az Országos Közegészségügyi Intézetben történt. A bakteriológiai leletek eredményét elemeztük, és vizsgáltuk, hogy van-e 
a normális baktériumflórától való eltérés. Patogénnek minősítettük a baktériumot a törzsi sajátossága, az észlelt csíraszáma alapján, a rutinszerú vizsgálat leletének megfelelően. A szövődményes eseteket súlyosságuk és lefolyásuk szerint csoportosítottuk. A 7-10 nap alatt spontán záródó nyálsipolyok eseteit „enyhe lefolyású” (nyolc eset) szövődmény csoportba soroltuk. Az elhúzódóan záródó, hegesedéssel és anastomosisszúkülettel járó eseteket, valamint a distalis anastomosisok oesophago/enterocutan sipollyal járó eseteit „közepesen súlyos” csoportba (18 eset) soroltuk. Közülük nyolc eset igényelt a kialakuló szúkület miatt tágító kezelést, amelyek közül négy esetben az eredménytelenség miatt az anastomosis sebészeti plasztikáját tette szükségessé. A tartósan fennálló sipoly miatt hat esetben volt szükséges öntáguló fémstent beültetése. A szeptikus állapotot, mediastinitist, empyema thoracist, peritonitist, abscessust eredményező eseteket a „súlyos” (12 eset) betegcsoportba soroltuk. Közülük két esetben az anastomosis lebontására és a pótlásra használt szerv eltávolítására volt szükség, négy esetben stentbeültetés, két esetben az anastomosis plasztikája és drenálás volt szükséges. Egy beteg esetében konzervatív detenzionáló kezelés elégségesnek bizonyult, egy esetben pedig a szeptikus állapot gyors és letalis progressziója miatt nem kerülhetett sor mútéti beavatkozásra. A súlyos szövődmények csoportjába sorolt betegek közül kilenc eset végződött exitussal (3. táblázat).

Az adatelemzéshez az IBM SPSS Statistics 22 programot használtuk. A szignifikancia szintjét $\mathrm{p} \leq 0,05$ értékben határoztuk meg. Az átlagok numerikus és százalékos értékeit, szélső értékeit, a standard deviációt (SD), a 95\%-os konfidenciaintervallumot (CI) ismertetjük. A de-

3. táblázat $\mid A z$ anastomosiselégtelenség kimenetele, súlyossága és a patogén baktériumflóra jelenléte a szájüregi mintában

\begin{tabular}{|c|c|c|c|c|c|}
\hline Insufficientia-következmény & Eset & & Súlyosság & \multicolumn{2}{|c|}{ Patogén flóra } \\
\hline Gyorsan záródó nyálsipoly & & 8 & Enyhe & 0 & \\
\hline Elhúzódóan záródó nyálsipoly & & 18 & $\begin{array}{l}\text { Közepesen } \\
\text { súlyos }\end{array}$ & 13 & $(72,2 \%)$ \\
\hline Stenosis kialakulása & 10 & & & 6 & $(33,3 \%)$ \\
\hline $\begin{array}{l}\text { Tágító kezelés } \\
\text { szükségessége }\end{array}$ & 8 & & & 6 & $(33,3 \%)$ \\
\hline $\begin{array}{l}\text { Anastomosisplasztika } \\
\text { szükségessége }\end{array}$ & 4 & & & 2 & $(11,1 \%)$ \\
\hline $\begin{array}{l}\text { Stentbeültetés } \\
\text { szükségessége }\end{array}$ & 6 & & & 5 & $(27,8 \%)$ \\
\hline Szeptikus állapot & & 12 & Súlyos & 10 & $(83,3 \%)$ \\
\hline $\begin{array}{l}\text { Pótlás mútéti eltávolítása } \\
\text { (Torek) }\end{array}$ & 2 & & & 2 & $(16,7 \%)$ \\
\hline Stentbeültetés + drenázs & 4 & & & 3 & $(25 \%)$ \\
\hline $\begin{array}{l}\text { Anastomosisplasztika + } \\
\text { drenázs }\end{array}$ & 2 & & & 2 & $(16,7 \%)$ \\
\hline Exitus & 9 & & & 7 & $(58,3 \%)$ \\
\hline Összesen & & 38 & & 23 & $(60,5 \%)$ \\
\hline
\end{tabular}

4. táblázat |Az orális baktériumflórában izolált patogén törzsek és előfordulási gyakoriságuk

\begin{tabular}{lcc}
\hline Patogén törzs & Pozitív minta & Gyakoriság \\
\hline Pseudomonas aeruginosa & 37 & $28,2 \%$ \\
Acinetobacter calcoaceticus & 24 & $18,3 \%$ \\
Acinetobacter baumannii & 4 & $3,1 \%$ \\
Staphylococcus aureus/MRSA & $15 / 4$ & $11,5 \% / 3,1 \%$ \\
Corynebacterium striatum & 10 & $7,6 \%$ \\
Klebsiella pneumoniae & 9 & $6,9 \%$ \\
Enterococcus faecalis & 7 & $5,3 \%$ \\
Escherichia coli & 7 & $5,3 \%$ \\
Streptococcus pyogenes & 5 & $3,8 \%$ \\
Streptococcus anginosus & 1 & $0,8 \%$ \\
Proteus vulgaris & 4 & $3,1 \%$ \\
Stenotrophomonas maltophylia & 4 & $3,1 \%$ \\
Enterobacter cloacae & 4 & $3,1 \%$ \\
Achromobacter xylosoxidans & 1 & $0,8 \%$ \\
Morganella morganii & 1 & $0,8 \%$ \\
Candida albicans & 8 & $6,1 \%$ \\
\hline Öszesen 131 beteg & 50 & $38,2 \%$ \\
\hline
\end{tabular}

mográfiai adatok elemzését független T-próbával, a Tpróba alkalmazhatóságának vizsgálatát a Levene-féle Fpróbával végeztük el.

Kerestük a korrelációt az anastomosiselégtelenség következményei és a baktériumflóra összetétele között. Az összefüggésvizsgálat során a Spearman-féle korrelációs együtthatót alkalmaztuk.

\section{Eredmények}

A 131 vizsgált beteg közül 102 férfi, 29 nő volt, átlagéletkoruk: 63,2 (34-84) év; SD: 9,74; 95\%-os CI: 61,60-64,96 volt.

A vizsgált 131 mintában 50 esetben volt patogén kórokozó kimutatható (16 baktériumtörzs és egy sarjadzó gomba). Az egyes kórokozók előfordulási gyakoriságát a 4. táblázat mutatja be. 39 mintában több törzs egyszerre, 11 esetben egyetlen törzs volt kimutatható (Pseudomonas spp. négy, Staphylococcus spp. három, Streptococcus spp. három és Candida spp. egy esetben). A kimutatott 15 Staphylococcus aureus törzs közül négy methicillinrezisztens (MRSA) volt. A patogén ágensekkel rendelkező betegek átlagéletkora: 63,6 (42-84) év; SD: 9,21; 95\%-os CI: 60,3-66,78 volt; férfi/nő arány: 40/10. A patogén ágensekkel nem rendelkező betegek átlagéletkora: 63,5 (34-84) év; SD: 9,67; 95\%-os CI: 60,06-66,75; férfi/nó arány: $62 / 19$ volt. A két betegcsoport átlagéletkora között statisztikailag nem volt szignifikáns eltérés ( $\mathrm{p}=0,960$; az F-próba nem mutatott szignifikáns különbséget a szórásban, $\mathrm{F}=0,944$ ). 
A 38 anastomosiselégtelenség esete közül 23-nál $(60,5 \%)$ volt a vizsgált mintában patogén kórokozó. Az „enyhe lefolyású szövődmény” csoportjába került betegeknél (nyolc eset) nem volt patogén ágens a mintákban (3. táblázat). A „közepesen súlyos lefolyású” betegcsoportban (18 eset) 13 esetben volt patogén kórokozókat is tartalmazó a minta $(72,2 \%)$. A „súlyos” betegcsoportban (12 eset) 10 esetben $(83,3 \%)$ volt patogén ágenseket is tartalmazó a vizsgált minta. A szövődmény súlyossága és a patogén ágenseket tartalmazó minták előfordulási gyakorisága között a korrelációanalízis a Spearman-féle korrelációs együttható vizsgálatával közepes erősségű kapcsolatot mutatott, $\mathrm{r}_{\mathrm{s}}=0,553$ értékkel. Az eredmény szignifikáns volt $(\mathrm{p} \leq 0,01)$.

\section{Megbeszélés}

A szájüregi flóra betegségekkel való összefüggése ismert, ám a mindennaposnak tûnő gondolat [7] jelentőségéhez képest mégis kevés figyelmet kap a modern medicinában. A normális flóra változatos előfordulási gyakorisággal, több száz különböző baktériumfajt tartalmaz [8-10], amelyek a szájüreg különböző pontjain és a fogak felszínén lévő biofilmben eltérő mértékben képesek megtelepedni. A szájüregi normálflóra tagjai között találhatók folyamatosan jelen lévő rezidens és időszakosan megjelenő tranziens baktériumfajok (1. táblázat). Az adott baktérium patogenitásának fogalma csak a beteg és bakteriális környezet védekezőképességével együtt értelmezhető. A potenciálisan kórokozó sajátosságú, megfelelő csíraszámban jelen lévő opportunista (fakultatív patogén) kórokozók a szövet közti térbe kerülve szeptikus folyamatok elindítói lehetnek. A normális szájüregi flóra állandó változást mutat mind csíraszám, virulencia, mind a törzsek fajtája terén, emellett eleve patogén törzsek megjelenése és kolonizációja észlelhető kóros körülmények következtében. A kolonizációt elősegítő tényezők közül a nyelőcsőtumoros beteganyagban kiemelkedően sokat megtalálhatunk. A szájüreg és felső gastrointestinalis traktus baktériumflórájának feltérképezése nehéz mikrobiológiai feladat a baktériumtörzsek gyakran nehézkes és bizonytalan kimutathatósága miatt.

Vizsgálatunk során a levett minták rutinszerü feldolgozása nem törekedhetett a nyelőcsőtumoros betegek bakteriológiai térképének pontos felvázolására, csupán a normálistól való eltérés kimutatását célozta. A mintavétel mütét közeli időpontját fontosnak gondoltuk. A tapasztalt 38,2\%-os eltérés ezen betegeknél számos jól definiálható okkal magyarázható: etil- és nikotinaddikció (gyenge immunstátusz és a légúti ciliaris funkció károsodása), pangó nyelőcsőtartalom (bakteriális felülnövekedés), malnutríció (gyenge immunstátusz), preoperatív radioés kemoterápia okozta állapot, társbetegségek, fogak szuvasodása, fogak hiánya (személyes higiénés állapot, rágás hiánya, a protézisek sajátos bakteriális flórája, nyálelválasztás következményes változásai), nosocomialis tényezők (hospitális kontamináció), lelki tényezők (be- tegségtudat, elhanyagoltság, mozgáshiány), tumoros alapbetegség (általános szomatikus leromlás). Az okok egyénileg eltérő súllyal, de mindig egymással összefüggésben jelentkeztek. A más vizsgálók által is felismert multifaktoriális jellegre irodalmi adatok is felhívják a figyelmet [11]. A vizsgálatunk során kimutatott bakteriális flóra törzsei más szerzők hasonló beteganyagon végzett vizsgálataival hasonlatosságot mutatnak [9, 11-14].

A nyelőcsőanastomosis-elégtelenség gyakorisága a nyaki anastomosisoknál 4-34\%, az intrathoracalis szakaszon $5-17 \%$, a distalis szakaszon $0,5-11 \%$ [1, 2, 15-19]. A nyaki anastomosisok esetében nyálsipoly, perioesophagealis phlegmone, abscessus alakulhat ki. A nyaki szakasz insufficientiáinak mortalitása $10-30 \%[1,3]$. A nyálsipolyok jelentős része rövid időn belül spontán záródással gyógyul. A környezeti gyulladásos folyamatok miatt és az elhúzódó záródást mutató esetekben az anastomosis szúküulete alakul ki, amely tágító kezeléseket, ezek sikertelensége esetén mütéti korrekciót (anastomosisplasztika) igényel. Az insufficientia lezárására megfelelő morfológiai feltételek esetén öntáguló fémstent is alkalmazható (anyagunkban összesen tíz eset, 1. 3. táblá$z a t)$. A súlyosabb phlegmonéval, abscessussal járó esetek mütéti kezelést igényelnek. Az intrathoracalis szakaszon kialakuló insufficientiák mediastinitist, mellüregi empyemát okozva magas mortalitást (50-70\%) eredményeznek [1-3, 15-18], általában reoperációt tesznek szükségessé. $\mathrm{Az}$ alsó harmadi és abdominalis nyelőcsőszakaszon készült anastomosisok elégtelensége kapcsán peritonitis, abdominalis abscessus, ritkán oesophago/enterocutan sipolyok alakulhatnak ki, a mortalitás $25-30 \%$ a közlések szerint $[1,2,4,16,20-23]$.

A nyelőcsőanastomosis-elégtelenség létrejöttének rizikófaktorai általában többszörösen és egyedi módon érvényesülnek. A fontosabb tényezők közé tartozik a beteg általános állapota: anyagcsere-tápláltság, társbetegségek, kísérő betegségek, általános keringési viszonyok (volumen, ozmolaritás, oxigéntranszport-kapacitás), légzőszervi viszonyok (szaturáció, respiratorikus tartalékok); mütéttechnikai tényezők: preparálási technika, anastomosis típusa (egyrétegű, többrétegű, teleszkópos), anastomosis helye (nyaki, intrathoracalis, distalis), a pótlás útja (orthotopicus, retrosternalis, abdominalis), a varróanyag sajátosságai (atraumatikus, monofil, sodrott, vastagság), a mütéti idő, mútéti vérvesztés (transzfúzióigény, pótlás megtörténte); a narkózisvezetés tényezői: intraoperatív folyadékterápia, vazopresszorigény és alkalmazás; a mütéti előkészítés tényezői: pótlásra használt szerv állapota, szájüreg-nyelőcső bakteriális flórája; a posztoperatív viszonyok: keringési státus (mikrocirkulációs viszonyok), légzési státus (oxigenizáció), intrakavitális nyomásviszonyok (drenázs, detenzionálás) $[2,5,6$, $15,23-27]$.

A kimenetel súlyosságára vonatkozóan Bardini, Csendes és Dindo végzett elemző felosztást [2, 20, 28], az általunk végzett besorolás lényegében hasonló elveket követett. 
A nyelőcsőtumor-betegségben szenvedő betegek szájüregi flórájának normálistól való eltérése, patogén törzsekben való gazdagsága nagyobb kockázatot, súlyosabb kimenetelt eredményez a varratelégtelenség eseteiben. A szájüreg flórája tehát meghatározó tényező a szövődmények kimenetele szempontjából.

A szájüregi flóra patogenitásának szerepe lehet a szövődmény kialakulásában, de ez a nagyszámú más tényező mellett nehezen bizonyítható. A kialakított anastomosis szájüregtől való távolsága (anastomosislokalizáció) szintén meghatározó jelentőségű lehet, a patogén ágensek hatásának érvényesülésében.

A szájüregi flóra mûtét előtti dekontaminációjával a posztoperatív pneumoniák gyakoriságának csökkenését (Hiramatsunál 22,4\%-ról 3,8\%-ra [13]) több vizsgálat is észlelte $[12,29]$. A dentalis plakkok mint bakteriális rezervoárok jelentőségét is több vizsgálat igazolta $[8,9$, $11,12,14,30]$.

A szájüregi flóra fakultatív patogén komponenseinek befolyásolásával kapcsolatosan Berry és mtsai 55 vizsgálat [9], Lam és mtsai 522 közlemény [11] adatait dolgozták fel. A csíraszám csökkentésére mechanikus intervenciók és többféle kémiai ágens kombinációját vizsgálták. A közlések a mechanikus fogmosás technikája, gyakorisága, a használt fogkrém, fogkefe (elektromos, hagyományos) és a szájöblítésre használt ágens hatóanyagának vonatkozásában tesznek javaslatokat. A szájöblítésre használt oldatok hatóanyagai a vizsgálatokban povidon-jód (polivinilpirrolidin), klórhexidin-glukonát, nátrium-fluorid, nátrium-benzoát, bikarbonátoldat, benzidamin-hydroclorid, citromsavoldat, glicerin, hidrogén-peroxid, alkohol voltak, amelyek különböző koncentrációkban kerültek alkalmazásra. A nyáltermelődés serkentésére rágógumit alkalmaztak $[9,11]$. Az eredmények a mechanikus és kémiai módszerek kombinációjának eredményességét sugallják, amely alapja lehet egy műtéti előkészítés kapcsán bevezetendő eljárásnak.

A szájüregi flóra a preoperatív hospitalizáció kapcsán hospitális, multirezisztens törzsek kolonizációjával is gyarapodhat [30]. Napjaink tendenciái egyrészt a preoperatív kórházban töltött idő csökkentését célozzák, de számos esetben a beteg állapota miatti előkészítés kórházi bentfekvést igényel.

A kialakuló szövődmény kezelésében az antibiotikumválasztáshoz segítséget nyújthat a szájüregi flórának és antibiotikum érzékenységének ismerete, de a rutinszerüen alkalmazott mütét előtti antibiotikum-profilaxis és a szövődmény zajlása a bakteriális képet jelentősen megváltoztatja, ezért a későbbiekben a mütét előtti mintavétel eredményeire már nem lehet támaszkodni.

A szájüregi flórának az anastomosis szövődményeivel kapcsolatos összefüggése ez idáig jelentőségéhez képest keveset vizsgált terület volt. A műtéti előkészítés során nagy figyelmet érdemel a szájflóra összetétele, így a mütéti előkészítés gyakorlatának megváltoztatása látszik szükségesnek. A patogén szájüregi flóra eradikációja jelentősen csökkentheti a szövődmények súlyosságát.
Anyagi támogatás: A szerzók anyagi támogatásban nem részesültek.

Szerzői munkamegosztás: B. Á.: Adatgyưjtés, -feldolgozás, -értékelés, statisztikai elemzés, szövegszerkesztés. W. B.: Adatgyűjtés, -feldolgozás, -elemzés. K. K.: Bakteriológiai vizsgálatok, feldolgozás. H. L.: Szövegszerkesztés. B. L.: Feldolgozás, értékelés. A cikk végleges változatát valamennyi szerző elolvasta és jóváhagyta.

Érdekeltségek: A szerzőknek nincsenek érdekeltségeik.

\section{Irodalom}

[1] Müller, J. M., Erasmi, H., Stelzner, M., et al.: Surgical therapy of oesophageal carcinoma. Br. J. Surg., 1990, 77(8), 845-857.

[2] Bardini, R., Asolati, M., Ruol, A., et al.: Anastomosis. World J. Surg., 1994, 18(3), 373-378.

[3] Crofts, T. J.: Ivor-Lewis oesophagectomy for middle and lower third oesophageal lesions - how we do it. J. R. Coll. Surg. Edinb., 2000, 45(5), 296-303.

[4] Schuchert, M. J., Luketich, J. D., Landreneau, R. J.: Management of esophageal cancer. Curr. Probl. Surg., 2010, 47(11), 845946.

[5] Girard, E., Messager, M., Sauvanet, A., et al.: Anastomotic leakage after gastrointestinal surgery: Diagnosis and management. J. Visc. Surg., 2014, 151(6), 441-450.

[6] Kanaji, S., Ohyama, M., Yasuda, T., et al.: Can the intraoperative leak test prevent postoperative leakage of esophagojejunal anastomosis after total gastrectomy? Surg. Today, 2016, 46(7), 815820.

[7] Atanasova, K. R., Yilmaz, Ö.: Prelude to oral microbes and chronic diseases: past, present and future. Microbes Infect., 2015, 17(7), 473-483.

[8] Aas, J. A., Paster, B. J., Stokes, L. N., et al.: Defining the normal bacterial flora of the oral cavity. J. Clin. Microbiol., 2005, 43(11), 5721-5732.

[9] Berry, A. M., Davidson, P. M., Masters, J., et al.: Systematic literature review of oral hygiene practices for intensive care patients receiving mechanical ventilation. Am. J. Crit. Care, 2007, 16(6), $552-562$.

[10] Majumdar, S., Singh, A. B.: Normal microbial flora of oral cavity. J. Adv. Med. Dent. Sci. Res., 2014, 2(4), 62-66.

[11] Lam, O. L., McGrath, C., Li, L. S., et al.: Effectiveness of oral hygiene interventions against oral and oropharyngeal reservoirs of aerobic and facultatively anaerobic gram-negative bacilli. Am. J. Infect. Control, 2012, 40(2), 175-182.

[12] Akutsu, Y., Matsubara, H.: Perioperative management for the prevention of postoperative pneumonia with esophageal surgery. Ann. Thorac. Cardiovasc. Surg., 2009, 15(5), 280-285.

[13] Hiramatsu, T., Sugiyama, M., Kuwabara, S., et al.: Effectiveness of an outpatient preoperative care bundle in preventing postoperative pneumonia among esophageal cancer patients. Am. J. Infect. Control, 2014, 42(4), 385-388.

[14] Yoshioka, M., Hinode, D., Yamamoto, Y., et al.: Alteration of the oral environment in patients undergoing esophagectomy during the perioperative period. J. Appl. Oral Sci., 2013, 21(2), 183189.

[15] Whooley, B. P., Law, S., Alexandrou, A., et al.: Critical appraisal of the significance of intrathoracic anastomotic leakage after esophagectomy for cancer. Am. J. Surg., 2001, 181(3), 198203.

[16] Sampaio, J. A., Waechter, F. L., Pereira-Lima, J., et al.: Succesful treatment of esophagojejunal disconnection after total gastrectomy by insertion of a covered self-expandable esophageal metallic stent. Gastrointest. Endosc., 2003, 58(3), 453-456. 
[17] De Liaño Argüelles, Á. D., García, G. S., Irazábal, C. Ү., et al.: Oesophagogastric anastomosis complications in the Ivor Lewis operation. Cir. Esp., 2011, 89(3), 175-181.

[18] Rutegård, M., Lagergren, P., Rouvelas, I., et al.: Intrathoracic anastomotic leakage and mortality after esophageal cancer resection: A population-based study. Ann. Surg. Oncol., 2012, 19(1), 99-103.

[19] Okabe, H., Obama, K., Tanaka, E., et al.: Functional end-to end esophago-jejunal anastomosis using linear staplers following laparoscopic total gastrectomy. Transl. Gastrointest. Cancer, 2013, 2(2), 81-82.

[20] Csendes, A., Diaz, J. C., Burdiles, P., et al.: Classification and treatment of anastomotic leakage after extended total gastrectomy in gastric carcinoma. Hepatogastroenterology, 1990, 37, 174-177.

[21] Lang, H., Piso, P., Stukenborg, C., et al.: Management and results of proximal anastomotic leaks in a series of 1114 total gastrectomies for gastric carcinoma. Eur. J. Surg. Oncol., 2000, 26(2), 168-171.

[22] Andreollo, N. A., Lopes, L. R., Coelho Neto, J. S.: Postoperative complications after total gastrectomy in the gastric cancer. Analysis of 300 patients. ABCD Arq. Bras. Cir. Dig., 2011, 24(2), 126-130.

[23] Weledji, E. P., Verla, V.: Failure to rescue patients from early critical complications of oesophagogastric cancer surgery. Ann. Med. Surg., 2016, 7, 34-41.

[24] Briel, J. W., Tambankar, A. P., Hagen, J. A., et al.: Prevalence and risk factors for ischemia, leak, and stricture of esophageal anasto- mosis: Gastric pull-up versus colon interposition. J. Am. Coll. Surg., 2004, 198(4), 536-541.

[25] Cassivi, S. D.: Leaks, stricures and necrosis: a review of anastomotic complications following esophagectomy. Semin. Thorac. Cardiovasc. Surg., 2004, 16(2), 124-132.

[26] Deguchi, Ү., Fukagawa, T., Morita, S., et al.: Identification of risk factors for esophagojejunal anastomotic leakage after gastric surgery. World J. Surg., 2012, 36(7), 1617-1622.

[27] Kiudelis, M., Bernotas, J., Mickevičius, A., et al.: Risk factors of esophagojejunal anastomosis leakage after total gastrectomy. Lithuanian Surg., 2013, 12(2), 20-24.

[28] Dindo, D., Demartines, N., Clavien, P. A.: Classification of surgical complications: a new proposal with evaluation in a chohort of 6336 patients and results of a survey. Ann. Surg., 2004, 240(2), 205-213.

[29] Atkins, B. Z., D'Amico, T. A.: Respiratory complications after esophagectomy. Thorac. Surg. Clin., 2006, 16(1), 35-48.

[30] Pedersen, P. U., Larsen, P., Hảkonsen, S. J., et al.: The effectiveness of perioperative oral hygiene in reduction of postoperative respiratory tract infections after thoracic surgery in adults: a systematic review. JBI Database of Systematic Reviews and Implementation Reports, 2012, 10(28), 1-12.

(Balázs Ákos dr., Budapest, Üllői út 78., 1082 e-mail: a.balazsdr@gmail.com)

\section{TÉVESZMÉK AZ ALTERNATIV GYÓGYÁSZATBAN?}

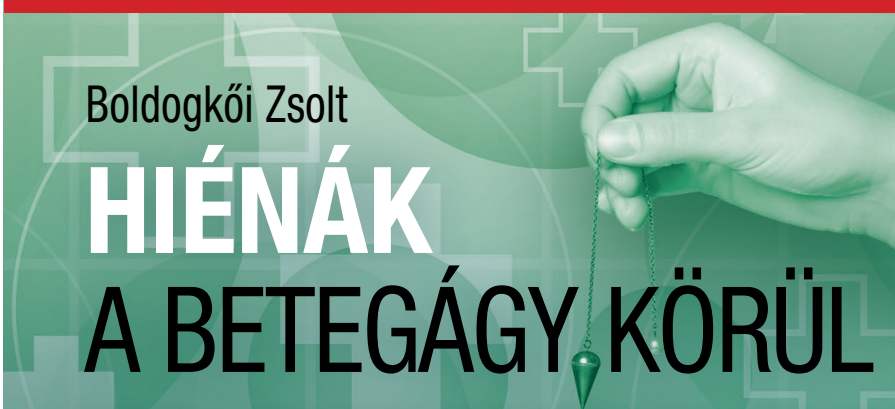

A szerző molekuláris biológusként elszántan küzd az áltudomány és a beteg ember kiszolgáltatott helyzetét kihasználó „kuruzslás” ellen. Könyvében a következő kérdéseket veti fel, állásfoglalása egyértelmü:

- Van-e tudományos alapja az íriszdiagnosztikának, homeopátiának, lúgosításnak, energiamezóknek?

- Miért csökken a tudományos gyógyítás presztízse, míg az alternativ gyógyítás népszerüsége egyre nő?

- Hogyan mérhető a terápia, a diéta hatása, miért hisznek a betegek csodaszerekben?

- Miért hajlandók sokan komoly összeget áldozni kétséges hatású terápiákra, szerekre, gyógyhatású készitményekre?

320 oldal, $3400 \mathrm{Ft}$ • világraszóló tudás • www.akademiaikiado.hu
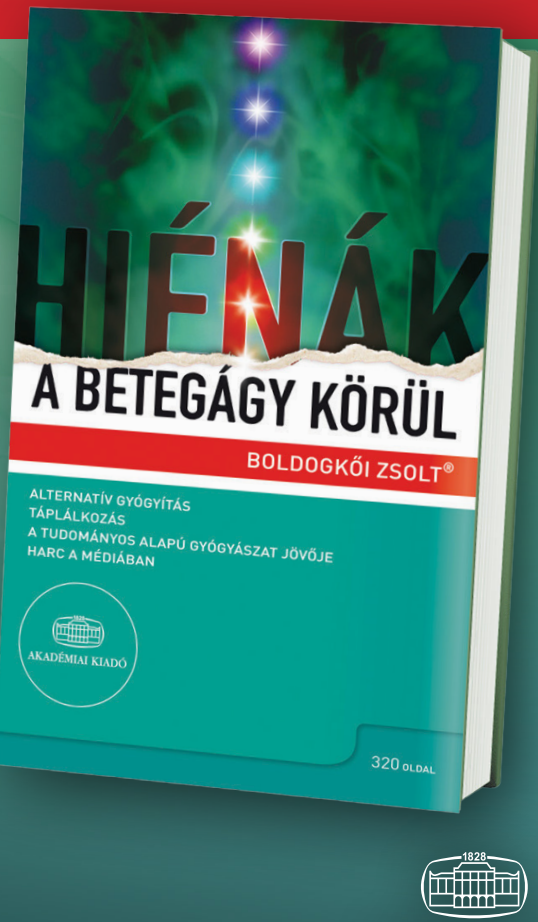

AKADÉMIAI KIADÓ 